\title{
A Linguistic and Gender Approach to 1841 Tuscany Population Census*
}

\author{
Manuela Sassi \\ Istituto di Linguistica \\ Computazionale "Antonio \\ Zampolli", Pisa, Italy
}

\author{
Stefania Biagioni \\ Istituto di Scienza e Tecnologie \\ dell’Informazione "Alessandro \\ Faedo", Pisa, Italy
}

\author{
Gabriella Pardelli \\ Istituto di Linguistica \\ Computazionale "Antonio \\ Zampolli”, Pisa, Italy
}

The Census of 1841 in Tuscany was the first official data registry which tried to describe Tuscan population as a whole on the basis of the Granducato's territory. With the use of special ad-hoc created forms, all demographic and socioeconomic characteristics of families and single persons in "Granducato di Toscana" were described. Work is developed in five points: (1) informatics retrieval of linguistic information from Tuscany of 1800 focused by the arts and craftsmanship more in use in families of that time; (2) gender division of works and craftsmanship; (3) observation of lexical disparity in the four communities and terminological curiosities of that historical period; (4) actually no longer existing craftsmanship; and (5) diachronic analysis of communities, where possible. In this scenario, the authors will introduce the methodology they used for data analysis. Tables and figures will be used to better focus different moments and results of the work. A Glossary in Appendix will contain the English translation of the Italian terms extracted from the Corpus.

Keywords: Tuscany Population Census, sociological analysis, gender analysis, the 19th work terminology, linguistic statistics, DBT (Textual Data Base) \& Facets, NLP (Natural Language Processing) tools

\section{Introduction}

The data of Census, maintained in the State Archive of Florence ${ }^{1}$ supply a precious source for studies of all different aspects of the population and include the following information: name, surname, age, gender, marital status, employment, religion, school, and "social status". In the registers for each community and for each parish, a full account is given of homes, resident families, and composition of families, including family servants. Each of those entities had a proper incremental code number.

Registers were generated and updated by priests, who at that time were the only surely educated officers widespread on territory. That is the reason why the registers are divided by parish, which is an administrative

\footnotetext{
${ }^{*}$ The first version of this paper has been presented in The 13th International Symposium on Social Communication (see Ref. Sassi et al. ii, 2013).

Manuela Sassi, researcher, doctor, CNR (National Research Council), Istituto di Linguistica Computazionale "Antonio Zampolli".

Stefania Biagioni, researcher, doctor, CNR (National Research Council), Istituto di Scienza e Tecnologie dell'Informazione "Alessandro Faedo".

Gabriella Pardelli, researcher, doctor, CNR (National Research Council), Istituto di Linguistica Computazionale "Antonio Zampolli”.

${ }^{1}$ Retrieved from http://www.archiviodistato.firenze.it/statocivile/.
} 
unit, typical of canonic right, instead of quarters or "rioni" or "contrade", which instead had been long practiced in civil right.

During early 1980s, the research group of professor Biagioli of Department of Modern History of Pisa University, charged the computational linguistic Institute of CNR (National Research Council) with digitalization and the electronic processing of these data as well as of data from Catasto $^{2}$ to enable statistical, demographical, historical, sociological, and economic analysis.

In this work, the authors have used the only partially usable subset of data extracted by that work, concerning four communities in the province of Pisa, i.e., actual Bièntina, Càscina, Pontedera, and San Giuliano Terme (at that time named "Baths of San Giuliano"). This work is more on terminological and lexical issues, with a gender related analysis of work and craftsmanship. Each of the four communities has its own peculiar profile.

\section{Methodology and Tools}

The software used for textual analysis and terms extraction is DBT-TP (Textual Data Base-Text Power) ${ }^{3}$. The DBT system is used for many projects, inside the Italian Scientific Community and abroad. The DBT is a software for textual analysis and full-text querying. DBT is a reference point in the literature and Italian language for text-based searches. The texts analyzed with the DBT system is structured in a proprietary format and is available for use by other application procedures via the access functionality that the system provides: (text or SGML/TEI (Standard Generalized Markup Language/Text Encoding Initiative)).

DBT \& Facets has been implemented by integrating the core textual search engine DBT with the TP technology ${ }^{4}$. DBT-TP is based on NLP (Natural Language Processing) techniques and linguistic resources used to create tools for the evaluation, analysis, classification, and browsing of information related to the domains of scientific literature. The extraction of implicit knowledge from the texts, through which TP can enrich the documents, is a specialization of the "Facets" technology. DBT-Corpus Query system of textual corpora, i.e., text collections of homogeneous texts structured, tagged, and pre-analyzed and query-able with database methods. The adopted methodology uses all of those capabilities, applying them to subsets of the data of the Census considered as a Corpus and structured on family records. Every analysis is based on ad-hoc created tables. These tables concern works and craftsmanship, which are subclassed as: (1) exclusively or typically male; (2) exclusively or typically female; and (3) shared or gender neutral works.

The total of the units (Male and Female) is 41,887, grouped in 7,190 families, and spread in four communities (see Figure 1).

Language oriented analytical reading of data has also brought to light the different phonetic and graphic forms of the various words in different communities, e.g., filandara (Bientina) and filandaja (San Giuliano) ${ }^{5}$ as well as in the same territory like the two forms "infima classe" and "bassa classe" used to point and label the low estate of a wood cutter (legnajolo) a miller (mugnaio) or a midwife (levatrice) ${ }^{7}$.

\footnotetext{
${ }^{2}$ Public registry of buildings and land ownership.

${ }^{3}$ Retrieved from http://dbtvm1.ilc.cnr.it/SitoDBT/ (DBT: developed by E. Picchi at ILC is a CNR trademark).

${ }^{4}$ Retrieved from http://dbtvm1.ilc.cnr.it/Faccette/DBT_e_Faccette.dll.

5 The use of the "j" sign indicates a long semi consonant "I" sound.

${ }^{6}$ Lowest class, sub proletariat

${ }^{7}$ See Appendix for the glossary and descriptions.
} 
Creation of ad-hoc taxonomies was also needed for the conceptual classification of different jobs and trade types (agricultural, textile, trade, professions, and craftsmanship).

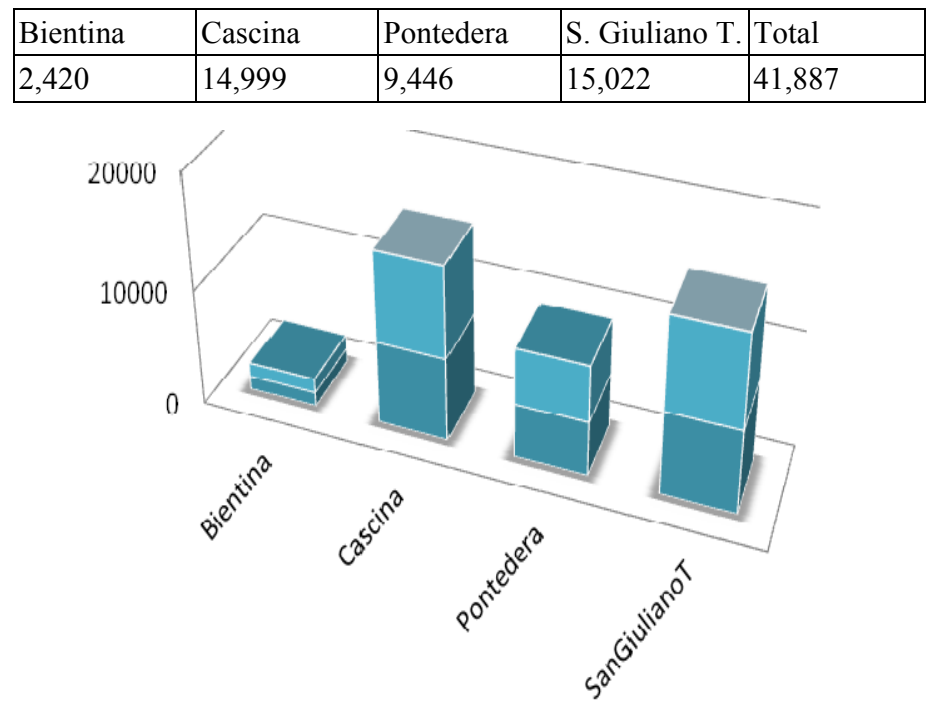

Figure 1. Communities/Women and men.

\section{Jobs Arts and Craftsmanship in Pisa Province in XIX}

Today's use-and-throw lifestyle was unconceivable then, so ordinary life goods were repeatedly fixed and arranged in order to be again fit to everyday's use. Whence over $70 \%$ of all craftsmanship was concerned and specialized primarily with such "Ars reparatoria" which enabled entire households to live on that income.

So there were calzettaja, calzolajo (shoe repair), canapajo, fabbro (blacksmith), fiascaja, manifattrice di pèneri (basket female crafter), seggiolaio (stool maker), zuccherinajo (that concerns the sugar), and all of them mostly repaired instead of crafting from scratching all everyday's objects.

Which occupations were recorded by the many priests of Tuscany territory in 1841 ? In which sectors was female work employed? Which types of jobs by men and women were indistinctly done?

\section{Noun Use in Craftsmanship Naming}

The sample of the four tuscanian communities sees (expectably) agricultural work ahead of any other activity. The voice colono/a (equivalent: farmer) lists 583 female and 1,695 male workers (about $4 \%$ of total population). To this single term, we must add both multi-word terms, like colono al monte (mountain farmer), lavoratore/trice al campo (countryside worker), or verbs containing label like lavora al campo (he/she works in the countryside). Terms like mezzajolo or mezzano, refer to people working on not their own country. This last term indicates the farmer working under contract, according to which he shares the harvest with the landowner. The multi-word contadino d'altri (farmer employee) indicates someone who works by year, or by shorter terms, soil of alien ownership either for money or for a crops share. By adding up all these labels we reach a total amount of 854 female and 2,663 male operators.

In this labeling, the priests, having in this crucial moment the role of "data collectors", made wide use of both their trained scholarship and their experience and specific knowledge of their territory, whence an heterogeneous lexicon for job definitions arose in the lists of the words employed to that end. For this reasons, we can detect significant differences even in neighboring municipalities. 


\section{Verb Use in Craftsmanship Naming}

Multi-word terms often include verbs and the most used are "andare" (to go), "fare" (to craft), "operare" (to operate or to act as), the graphic form that all these terms assumed may be very different. For the verb "andare", we have a basic significance "to move for working outside own home or land" but four quite distinct usages:

(1) Forms like: (a) Va a far legna in macchia (female), picks up [burning] wood in forest; (b) Va a scuola, for a (male) student; and (c) Va a raccogliere letame (male), (he goes to gather manure), in 1841 in Pontedera it was still a salable skill;

(2) Forms indicating works for third parties, like: (a) Va a bottega di calzolaro (male), indicates a male who goes to learn activity or help activity of a craftsman who produces and repairs shoes (there still is a surname indicating this craftsmanship in Italy and in several cities you can find streets titled to it); and (b) $\mathrm{Va}$ a opera a fare erba (female), weeds gatherer for other people (from Latin "opera", neutral plural voice indicating all paid jobs);

(3) Similarly, for verb "fare" we have: (a) the usage meaning to craft, like in Fa calze, (female) craftswoman producing stockings and socks; and (b) the usage meaning to execute a job like in:

-Fa scuola (teaches)

-Fa faccende a domicilio (domestic worker);

(4) Forms like verb "operare", meaning to act or to execute and usually employed in the present participle form, are shown in Table 1.

Table 1

Types of Work Categories

\begin{tabular}{|l|l|l|l|}
\hline $\begin{array}{l}\text { Labels referring directly to } \\
\text { agricultural works }\end{array}$ & $\begin{array}{l}\text { Referring to specific soil } \\
\text { products }\end{array}$ & $\begin{array}{l}\text { Indicating sale or trade of soil } \\
\text { products }\end{array}$ & $\begin{array}{l}\text { Pertaining to ownership of soil or } \\
\text { work contracts }\end{array}$ \\
\hline garzone di campagna & vinajolo & negoziante di grani & piccolo colono di proprietà \\
\hline lavora al campo & fruttajolo/fruttajola & negoziante di grasce & piccolo mezzajolo \\
\hline lavoratrice al campo & garzone di vinajolo & negoziante di legna & piccolo proprietario \\
\hline piccola colona & & negoziante di legna per forno & pigionale \\
\hline piccola colona a monte & & negoziante di olio & possidente, usufruttuaria \\
\hline piccolo agricoltore & & negoziante di vino & possidente agricoltore \\
\hline operante & & Ortolano/ortolana & possidente livello \\
\hline bracciante & & & poche terre possidente, operante \\
\hline
\end{tabular}

\section{Gender Split of Works in XIX in Pisa Province}

In which job sectors were women involved? An answer to this question required the categorization of all job and craftsmanship, which we made in 15 sectors and related sub categories (see Table 2).

To generate taxonomies (or Facets), each job label has been analyzed and inquired, and not all of them were at first sight comprehensible and exhaustive, thence we found necessary to resort to an etymological and historical dictionary of Italian language, i.e., the dictionaries of Accademia della Crusca in Florence. We associate to the sector labels defined above letters $\mathrm{M}$ for male and $\mathrm{F}$ for female in order to show the gender presence in different sectors (see Figure 2).

Semantic aggregation procedure has necessarily been of heuristic type, which explicitly means that several terms were moved across sectors in order to reach a correct conceptual distribution. Originally we had 24 job sectors, but we merged some of them to avoid dispersion of information so that finally we finish with 15 sectors. 
Table 2

Gender Presence in Different Sectors

\begin{tabular}{llrr}
\hline Settore & Sector & F & M \\
\hline agricolo & agriculture & 854 & 2,663 \\
apprendistato/studio & apprenticeship and learning & 3 & 30 \\
artigianale & craftsmanship & 25 & 462 \\
commerciale & Trade \& sale & 85 & 605 \\
servizi & services & 160 & 1,552 \\
domestico & domestic work & 2,766 & 131 \\
ecclesiastico & church & 0 & 113 \\
edile & building & 1 & 109 \\
legale & legal & 0 & 18 \\
medico e paramedico & medical and paramedical & 10 & 107 \\
metallurgico & metallurgy & 0 & 39 \\
militare & military & 0 & 115 \\
proprietà e mediazioni & ownership and intermediation & 36 & 30 \\
pubblico impiego regio & public administration & 7 & 269 \\
tessile & textile & 1,206 & \\
\hline
\end{tabular}

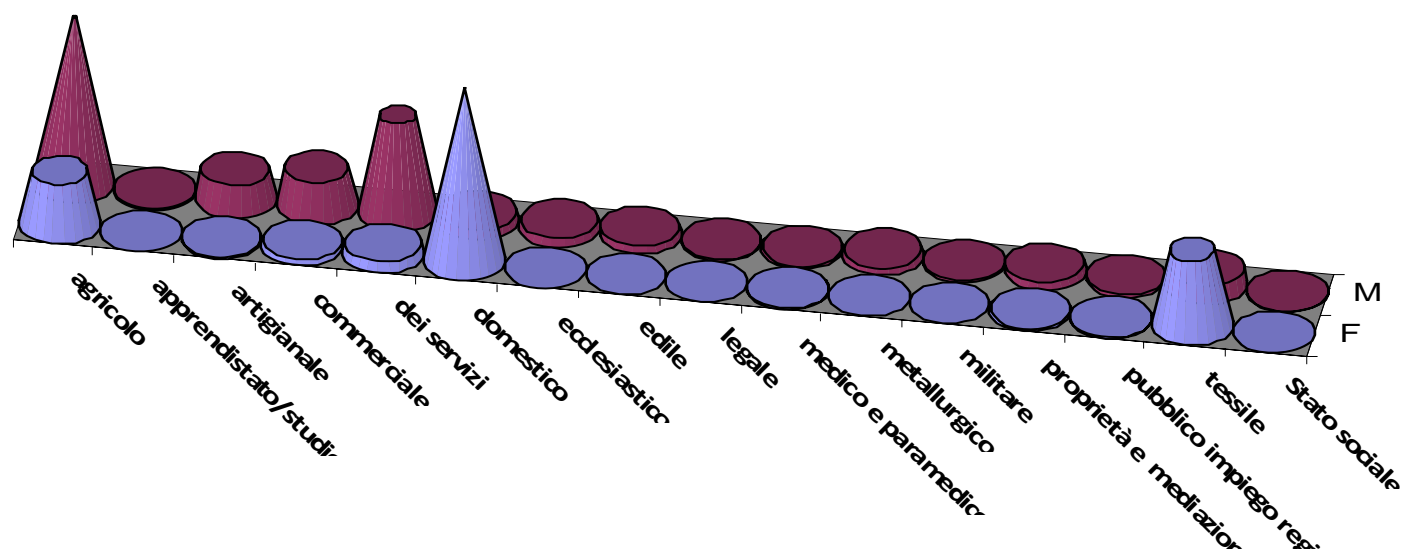

Figure 2. Gender presence in different sectors.

Notably we were forced to add a special category for brokering activities, which had a great relevance at that time and nowadays. The entire phenomenology of the work market entry has been classified under apprenticeship, e.g., impara l'arte del carratore, impara l'arte del calzolaro, and inizia a tessere canestre.

A special relevance was the domestic work sector, in which most of jobs are typically or exclusively female, like balia, domestica, and fa le faccende a domicilio.

The professional terms related to medical and veterinary work have resulted totally unambiguous. Service sector is a restricted version of the actual tertiary and includes works like vetturale, vetturino, nocchiero (indicates the activity of conducting ship in and out from harbors), stiratora, tintore/tintora.

In the trade and sale sector, we have extracted all related activities, even if the term in dictionaries presented semantical ambiguity between the producing craftsman and the seller, like fusajo, chincagliere.

In the craftsmanship sector, three subsectors have been created and considered as craftsman categories: metallurgy, textile works, and masonry. All jobs that have been admitted, or that are female-dominant, were extracted from single taxonomy. In that period, most of the out-of-home works were exclusively male. 
We can immediately see that agriculture is by far the dominating sector and also the most gender shared or neutral. Women and men shared countryside work (bracciante is gender free term) and organized it (fattore/essa, contadino/a, colono/a).

The second gender-shared sector is the textile craftsmanship, which we see in the terms: tessitore/a, sarto/a, while the threading work named filandaja/filandara/tessiera/tessitrice is exclusively female. Also commerce sector is shared, and we have terms like fornajo/a, fruttajolo/a, bottegajo/a; instead, commerce of tobacco and salt is exclusively male.

Medical sector has professions that are exclusive to each gender; the professions of medico and chirurgo are exclusively male, while ostetrica and levatrice are exclusively female.

Military, clergy, legal, and royal officials sectors are exclusively male, and we may observe that the terms suora and monaca are not listed in this Census.

Men and women reporting a job label are classified by their kinship relationship to the family head. In Figure 3 appears as bar-reference number on the left side; the work indicator [triangle] is measured on the total of individuals [cross] and the reference number is on the right side.

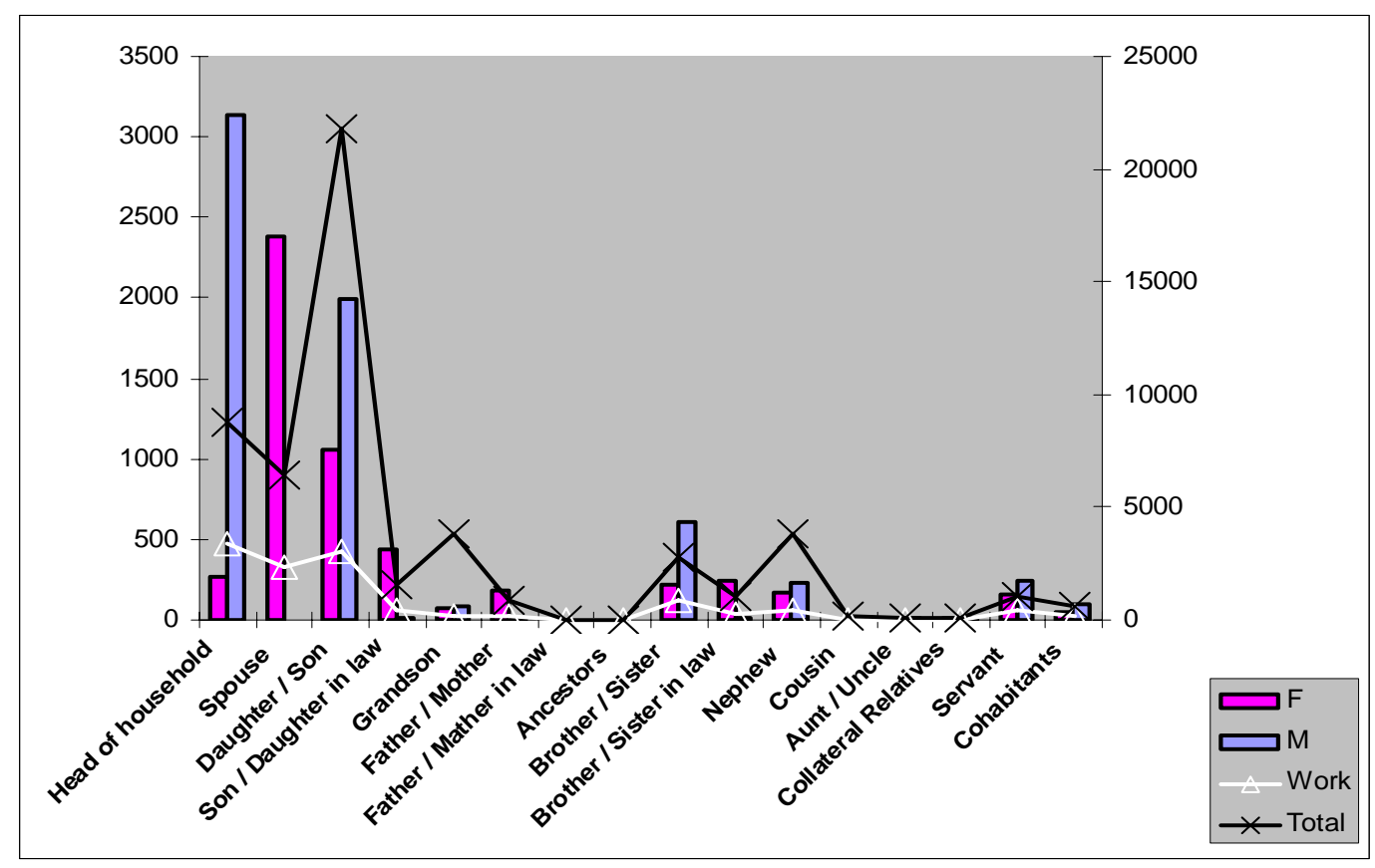

Figure 3. Work classified by family relationship.

\section{DBT-TP \& Facets Technology Applied to the Corpus}

The extraction of implicit knowledge from the text, through TP can enrich the documents, which is a specialization of the faceted technology (Facets). The Facets concept is peculiar of Archives and Library Science field, but is used in Information Retrieval too.

In Library Science the term "Facet" identifies the elements of a structured material such as library catalogs, which are characterized by the code of the field and its contents. TP extends the concept of Facets, extracting pairs "field + content" also from parts of the structure containing free text, typically bibliographic descriptions, abstracts, etc.

In this sample, the contents are extracted by the procedures of TP directly from the free text, using their 
linguistic-statistical approach and elevated to the rank of Facet. The facets are so extended; replacing them with the set of all terminology annotations that TP has automatically marked.

Tools that we have developed, starting from our base engine DBT and named "DBT \& Facets", can use the text so enriched for analysis, classification, query, and navigation.

The result of the query tessiera + canapajo shows both the relations among craftsmanship and family names (see Figure 4).

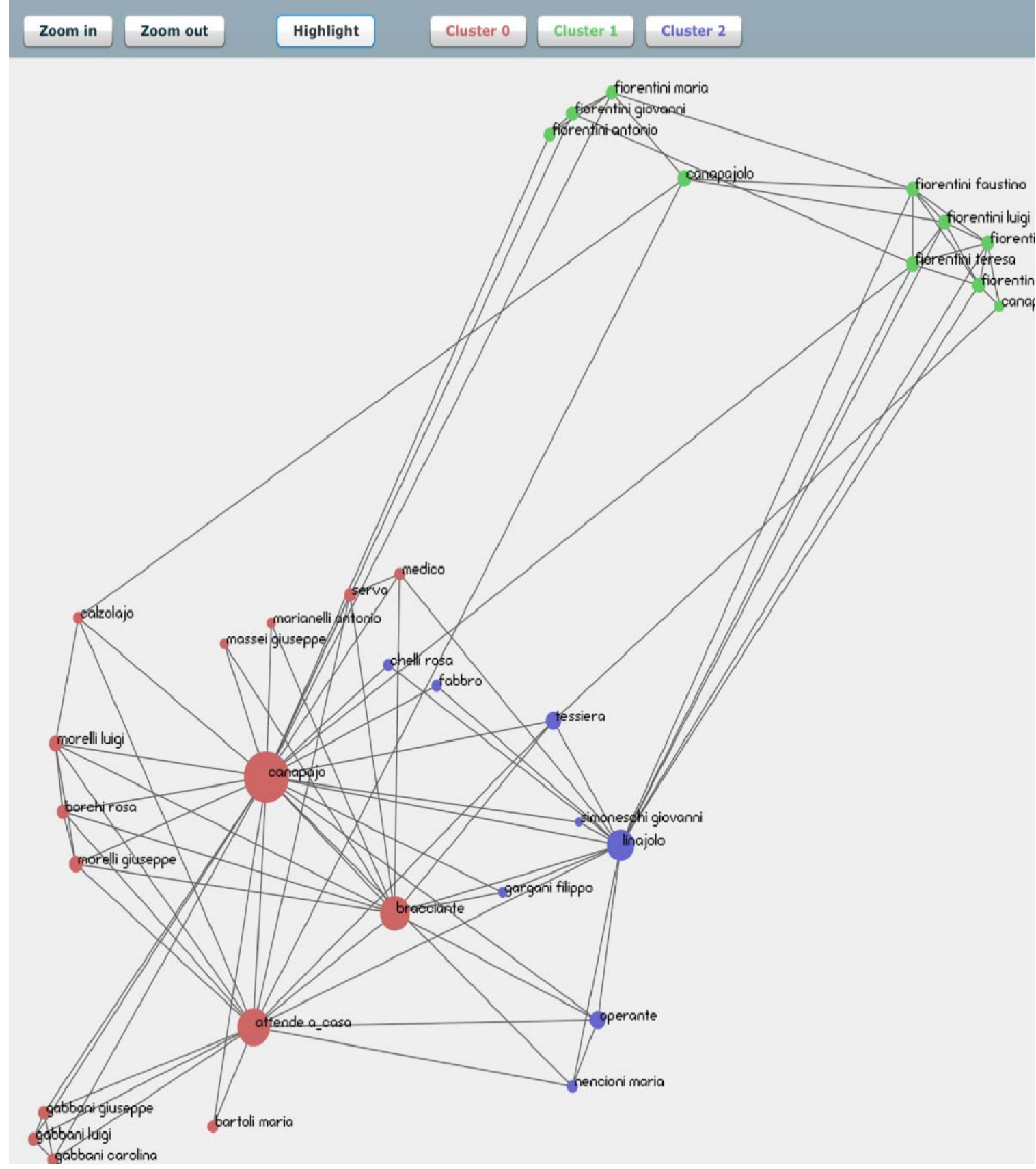

Figure 4. Query result of weaver + hemp worker. ${ }^{8}$

${ }^{8}$ The smaller circles represent the family groups. 


\section{Conclusions}

The study emphasizes that women have worked inside their home (the domestic work sector): In all communities, a total of 2,766 females are labeled with attende a casa, massaia, casalinga, etc.. Since ancient times, women have added to this in-home activity: threading, weaving, horticulture, and in some cases, the real fieldwork.

The textile work appears to be dominated by women whose 1,206 units are four times the number of males employed in that sector. Agriculture is still dominated by male; 2,663 units are more than thrice the number of females employed.

Rarely women practiced a single activity even if determining the percentage of activity results quite difficult by using the available information. For example, knitting and similar was made to supply an income instead of saturating the family necessities. Works like balia and serva surely required the compensation either in money or in form of "roof and food".

Surely, men too in that period added temporary activities, e.g., a craftsman might become a temporary agriculture unit, especially in times of scarcity.

Our final graph clearly shows that domestic work is the $54 \%$ of the whole female work; the major classes are textile work at $23 \%$ and agriculture $17 \%$ (see Figure 5).

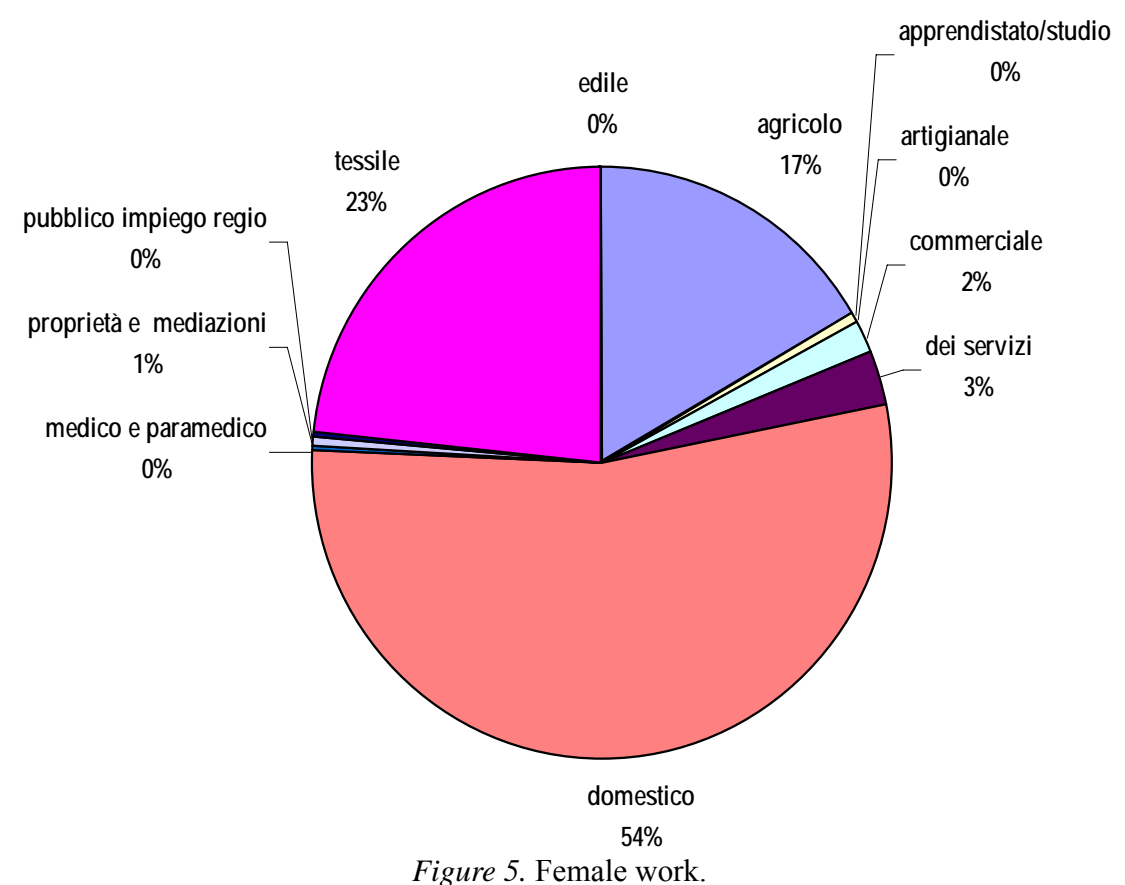

\section{References}

Biagioli, G. (1987). The spread of Mezzadria in central Italy: A model of demographic and economic development. In A. Fauve-Chamoux (Ed.), Evolution agraire et croissance démographique (Agrarian evolution and population growth). Atti del $X V I$ Congresso di Scienze Storiche, Stuttgart.

Biagioli, G. (2006). Le donne contadine del mondo a metà (The women farmers of the half world). In E. Fasano Guarini, A. Galoppini, \& A. Peretti (Eds.), Fuori dall'ombra: Studi di storia delle donne nella provincia di Pisa (Out of the shadows: Studies of women's history in the province of Pisa) (secoli XIX e XX, pp. 247-288). Pisa: PLUS.

Dal Pane, L. (1971). Industria e commercio nel Granducato di Toscana nell'età del Risorgimento (Industry and trade in the grand Duchy of Tuscany in the age of the Risorgimento). Bologna: R. Pàtron. 
Granucci, F. (2008). Esempi di lessico registrato nell'ultimo censimento del Granducato di Toscana (Examples of vocabulary registered in the last census of the Grand Duchy of Tuscany). Quaderni del Dipartimento di Linguistica-Università di Firenze, 18, 47-70.

Lotti, L. (Ed.). (2000). Storia della civiltà toscana (History of Tuscan civilization) (Vol. 4). Firenze: Le Monnier.

Pardelli, G., Sassi, M., Goggi, S., \& Biagioni, S. (2012). From medical language processing to BioNLP domain. In N. Calzolari, K. Choukri, T. Declerck, M. U. Doğan, B. Maegaard, J. Mariani, J. Odijk, \& S. Piperidis (Eds.), LREC’12—Proceedings of the eight international conference on language resources and evaluation (pp. 2049-2055). Istanbul: ELRA (European Language Resources Association).

Picchi, E., \& Sassolini, E. (2010). La tecnologia Text Power per la navigazione intelligente (Text Power technology for intelligent navigation). ORAAL-Convegno di inaugurazione dell'Osservatorio sulle Regole dell'Agricoltura e dell'Alimentazione, Pisa.

Picchi, E., Sassi, M., Biagioni, S., \& Giannini, S. (2010). Extending the "Facets" concept by applying NLP tools to catalog records of scientific literature. In D. J. Farace, J. Frantzen, \& GreyNet (Eds.), GL 12-Twelfth international conference on grey literature: Transparency in grey literature, grey tech approaches to high tech issues. Praga: Text Release.

Sassi, M., Biagioni, S., \& Pardelli, G. (2013). A linguistic and gender approach to 1841 Tuscany Population Census. In L. R. Miyares, M. R. Á. Silvay, \& A. M. Alvarado (Eds.), XIII international symposium on social communication (Vol. 1, pp. 200-205). Santiago de Cuba: Centro de Lingüística Aplicada, Ministero de Ciencia, Tecnología y Medio Ambiente.

\section{Appendix: Glossary}

arrotino $=$ grinder

Who sharpens knives and craft tools to cut

attendente (attende a...) = housewife (or soldier)

Woman that takes care of something (in the military environment: soldier awaits the personal service of an officer)

balia $=$ nurse

Who Breeds and feeds children

barrocciao, barrocciante $=$ carter

Who transports goods with a cart

bettolante = "bettolante"

1. Anyone who frequents taverns 2. Tuscan: owner of the tavern

boscaiolo $=$ woodman

1. Who cuts the wood 2. Who is responsible for the cultivation and care of forests

bracciante $=$ laborer

Who works in day as a laborer or farmer

braciao = "braciaio"

Who keeps the embers for reuse

bracino $=$ charcoal maker

Who makes or sells charcoal

calzettaia $=$ maker of stockings

1. Who makes, sells or repairs stockings. 2. A stocking factory worker

calzolaio $=$ shoemaker

Artisan who makes or repairs shoes of all kinds (craftsman)

canapaio $=$ hemp worker/seller

Who collects, works or sells hemp

cappellaio $=$ hatter

1. Who makes or sells hats mannish 2. Who, in falconry,put or put off the cap to rapacious carbonaio $=$ charcoal

1. Who makes charcoal in charcoal 2. Those who sell charcoal and firewood, wholesale or retail carradore $=$ wheelwright

Anyone who builds or repairs carts and wagons.

casiere $=$ caretaker

Tuscan: caretaker of a house 
cavatore $=1$. dentist/2-3. quarryman

1. Who pulls a tooth or blood 2. Workers involved in mining of the quarry: c. marble, stone, sand 3. Excavator cerchiaio = "cerchiaio"

Who manufactures or sells rims

chincagliere $=$ "chincagliere"

Who manufactures or sells knickknacks

chirurgo $=$ surgeon

Who practice surgery

ciabattino $=$ cobbler

Who repairs shoes, rare Manufacturer of slippers

colono $=$ settler

Farmer who grow for someone else's

contadino (lavora al campo) $=$ farmer

1. Who cultivate the land 2 . Inhabitant of the countryside

convivente $=$ cohabitant

Who entertains a marriage-like relationship with a person, without being legally married

corbellaio $=$ maker of baskets

Who makes baskets

domestica $=$ housekeeper, housemaid

Maid service

ecclesiastico $=$ churchman

Who belongs to the clergy

fa faccende a domicilio = hausemaid

Who do chores at home

fa scuola $=$ teacher

Who teaches at school or at home

fabbro $=$ smith

1. Artisan who works with iron and produces iron objects: f. blacksmith-Tinker: f. coppersmith, tinsmith 2. Ancient form: Manual worker in general, craftsman

fattore $=$ farmer

Person who carries on the management or direction of a farm

fiascaia $=$ maker of flasks

Who makes, stuff with straw or sells flasks

filandara, filandaja $=$ spinner woman

Who works in a textile mill

fornaio $=$ baker

Who cooks or sells bread

funzionario regio $=$ royal official

Who exerts particular functions or administrative directives

fusaio $=$ maker of spindle

Makers of spindles, person manufacturing or selling spindles

giubilato $=$ retired person

Who is retired

guardaroba $=$ keeper of the wardrobe

1. Ancient form for attendant of the cloakroom 2. Secret waiter that took care of the garments of the Pope guardiano 1 = guardian

Who is in charge of guarding, monitoring of places or property of others: g. a warehouse, a house, a lighthouse, g. horses, pigs (day or night watchman). [Synonymous with overseer]

guardiano 2 = prison guard

Who is the keeper of the prison 
guardiano 3 = guardian

Father superior of a convent (Franciscan order)

guardiano $\mathbf{4}$ = guardian father/guardian angel

Who is involved in the case of something

impotente $=$ impotent

Who does not have the power, the force required to work

inabile = unemployable

Who is unable to work

iniziato $a . .$. = initiate into...

That people who are trained in things that require specialized studies

legna, erba (va a far.) = gatherer of firewood or grass

Who gathers firewood or grass

legnaiuolo $=$ carpenter

1. Artisan who makes rough carpentry work 2 . Who is the roughing cutter and logs felled in the woods

letame (va a raccogliere...) = goes to collect manure

Who collects manure

libraio $=$ bookseller

1. Who sells books 2. Ancient form: amanuensis

magnano = "magnano"

Tuscan: Craftsman, often walking, running minute articles of iron as keys, locks, etc.- Tinker: person manufacturing boilers and

other containers, especially copper

medico $=$ physician, doctor

Who practice medicine professionally

mendicante, questuante $=$ beggar

Who begs, who lives by begging

mezzajolo $=$ sharecropper

Farmer who leads a fund sharecropping

militare $=$ soldier

Who belongs to a military

ministro $=$ minister

Who exerts an office, a ministry

muratore $=$ bricklayer

Who builds masonry

negoziante di grani = merchant grain

Who sells grain

negoziante di grasce = seller of pork fat, lard

Who sells pork fat, lard

negoziante di olio $=$ seller of olive oil

Who sells olive oil

negoziante di vino $=$ wine seller

Who sells wine

nocchiero $=$ steerer, steersman, helmsman

Who guides the ship

operante delle strade, stradino $=$ roadwork

Workers involved in the maintenance of roads. today Roadwork

operante mugnaio = miller

Who grinds wheat, oats. Grinder

orefice $=$ goldsmith

1. Those who work with precious metals and gems to make jewelry and other items 2 . Who sells cutlery

orfana $=$ orphan

Who is left devoid of one or both parents 
ortolano/ortolana $=$ greengrocer

1. Who, for commercial gain, cultivates a garden 2 . Who sells vegetables

ostetrica e levatrice $=$ midwife

Nurse specializing in assisting women in labor

pescatore $=$ fisherman

Who exercises the art of fishing

pettinaio = "pettinaio"

Who makes or sells combs

pigionale $=$ tenant

1. Tenant 2. Tuscan: Farmer who has rented a farm (renter)

possidente $=$ landowner

That the person who owns real estate, esp. land and homes, and lives all or part of their annuity

possidente usufruttuaria = landowner usufructuary

Who enjoys the usufruct of an asset

scalpellino o scarpellino $=$ stonecutter

1. Those who work or carve stone or marble with chisel 2. Sculptor of little or no value

scuola (va a.), scolaro $=$ pupil

Who goes to school

segantino $=$ sawyer

1. Who cuts by hand or machine the trunks of trees to obtain firewood or boards to reduce to woodworking 2. A day laborer to cut hay or grain, mower, reaper

segatore $=$ sawyer

1. Who saw for a living: sawyers of wood, marble, iron, sawing machine 2. Reaper

seggiolaio = chair maker; seller; mender/repairer

Who makes, repairs or sells chairs

sellaio $=$ saddler

1. person manufacturing, repairs or sells saddles or other leather items 2 . Who is in charge of conservation and repair of saddles and everything related to the equipment of quadrupeds

speziale $=$ apothecary

1. Who sold spices and medicinal herbs (The Art of doctors and apothecaries, in medieval Florence, the corporation that was one of seven major arts) 2. Pharmacist and Grocer

stiratora $=$ ironer woman

Who irons clothes and linens for the profession

suora $=$ nun

Belonging to a religious order or congregation with simple vows only

tessiera $=$ weaver woman

Who works to the loom

tintore/tintora. $=$ dyer

Who dyes fabrics and leathers. Who works in a dry cleaners, and whoever manages or owns

tornitore $=$ turner

Who polishes metals, wood

vetturale/vetturino $=$ driver/coachman

Who makes the job of transporting goods or people with beasts of burden or draft

vinajolo $=$ vintner

Who sells the wine wholesale or retail. Common Name: innkeeper

zuccherinajo $=$ confectioner

Who makes and sells candy 